\title{
United Nations gender network: first workshop report
}

Conference or Workshop Item

Published Version

O'Donoghue, A. and Freedman, R. (2017) United Nations gender network: first workshop report. In: UN Gender Network Workshop I, 28 Mar 2017, Reading University. doi: https://doi.org/10.2139/ssrn.2990391 Available at http://centaur.reading.ac.uk/98982/

It is advisable to refer to the publisher's version if you intend to cite from the work. See Guidance on citing.

Published version at: https://ssrn.com/abstract=2990391

To link to this article DOI: http://dx.doi.org/10.2139/ssrn.2990391

Publisher: United Nations Gender Network

All outputs in CentAUR are protected by Intellectual Property Rights law, including copyright law. Copyright and IPR is retained by the creators or other copyright holders. Terms and conditions for use of this material are defined in the End User Agreement. 


\section{CentAUR}

Central Archive at the University of Reading

Reading's research outputs online 


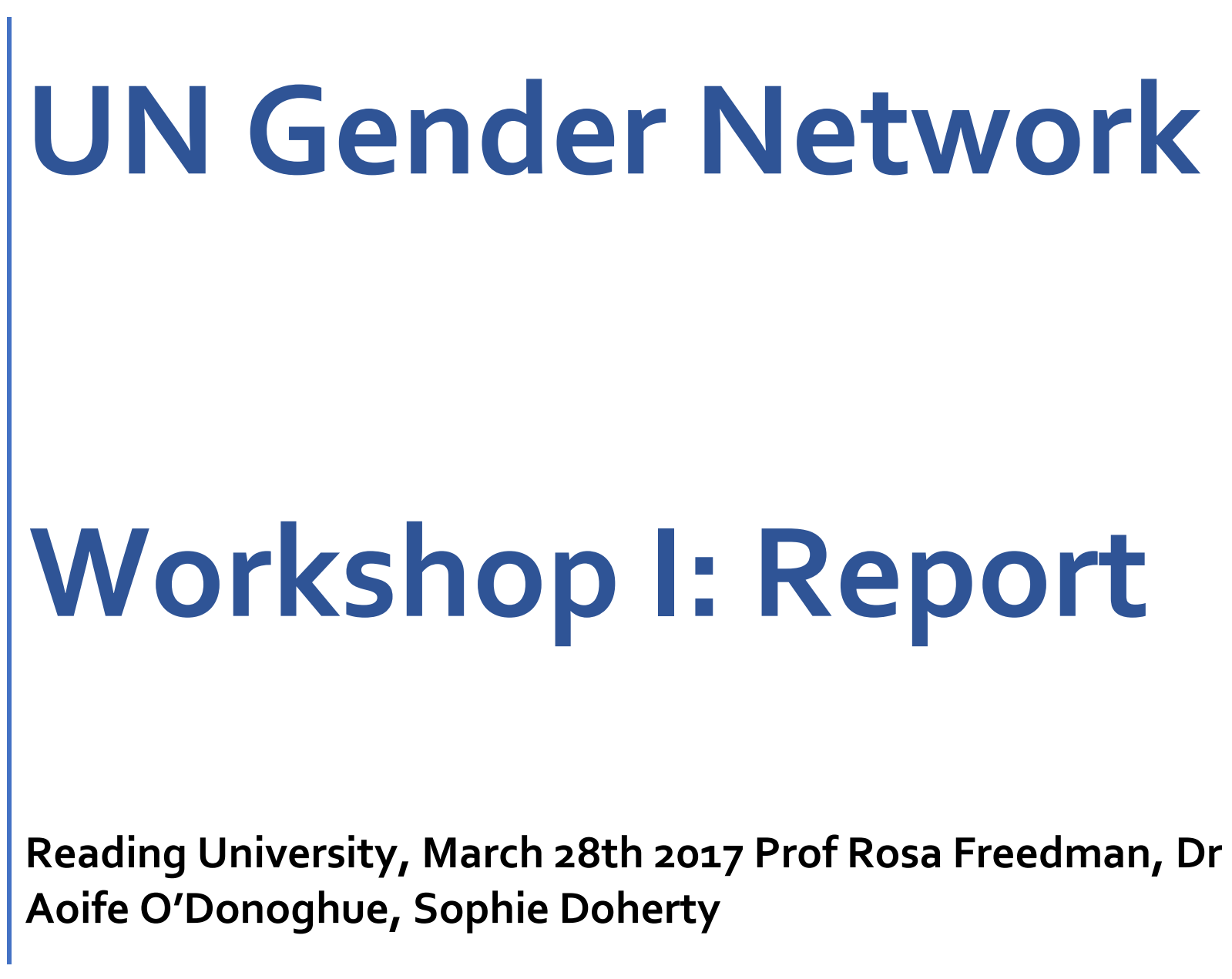




\section{Contents}

Introduction

2

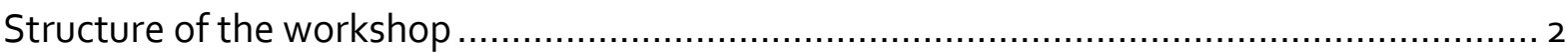

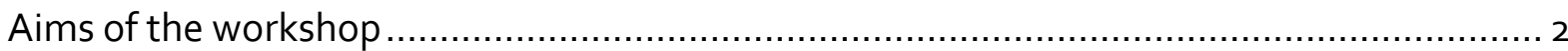

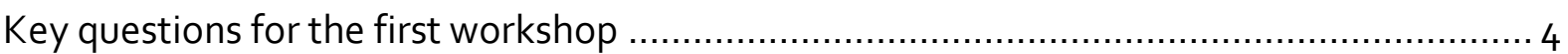

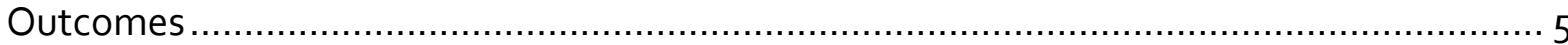

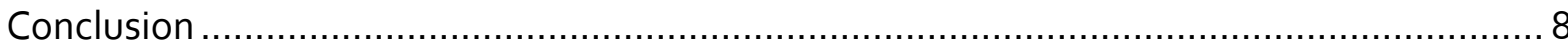

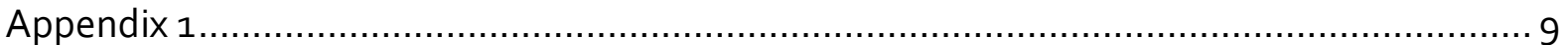




\section{Introduction}

This summary provides an overview of the first workshop of the UN Gender Network. The report will set out the structure of the workshop, its aims, the key questions addressed, and the workshop.

\section{Structure of the workshop}

On the $28^{\text {th }}$ March, the UN Gender Network held their first meeting at the University of Reading. ${ }^{1}$ The event was led by $\operatorname{Dr}$ Aoife $\mathrm{O}^{\prime}$ Donoghue of Durham University (PI) and Professor Rosa Freedman of University of Reading ${ }^{2}$ (CO-I). The attendees were divided into roundtable groups of approximately four to five participants. The first session was led by the PI and CO-I exploring and opening up for discussion key statistics and issues set out on a PowerPoint. The PowerPoint explored the current representation of women in the UN and the current state of play. At regular intervals, members of the network were presented with discussion topics to facilitate conversation and ideas on the actions and issues that the network should address.

\section{Aims of the workshop}

There were four aims of the first workshop:

1. To establish a transnational UN Gender Network that includes academics, civil society, UN staff, and states.

2. To harness expertise from academia and civil society in the co-production of a research project agenda to understand the cause and impact of gender inequality within the UN and its impact upon the UN's leadership and legitimacy in the operationalisation of the Sustainable Development Goals.

3. To use the network's activities as a platform from which to develop effective policy recommendations to the UN and states for reform and to underpin the implementation of the SDGs, particularly Goal 5 on women and girls.

\footnotetext{
${ }^{1}$ The list of attendants is included in Appendix 1.

${ }^{2}$ Assisted by Sophie Doherty, Durham University.
} 
4. To ensure the network's sustainability through the active participation of postgraduate and early career researchers alongside establishing effective collaboration amongst the transnational participants 


\section{Key questions for the first workshop}

Throughout the first workshop, participants were asked to keep in mind the following questions:

- What do we mean by 'gender' at the UN? How do we address issues of intersectionality within an Organisation that is, by its very nature, 'elite'?

- What constitutes gender equality within institutions and organisations? How has that equality been implemented and actualised within institutions and organisations?

- What does gender look like within the UN and where are the gaps, flaws, and weaknesses?

- How can lessons be learnt from other organisations or institutions in order to address the gender inequality within the UN?

- How does national culture, ideology, law, or identity impact upon gender equality or inequality?

- What structures exist at the local, national, regional, international, or global levels to address gender inequality?

- What internal structures exist within the UN to address the gender question? How well do they function? What else needs to be done?

- Given that the UN is a collection of member states, what obligations and responsibilities do they have to address the gender question? 


\section{Outcomes}

There were three key themes explored during discussions: measuring inequality, barriers to inequality, and defining 'sex vs gender' for the purposes of the workshop.

\section{a) Measuring Gender Inequality/Equality}

Firstly, the issue of measuring gender inequality was highlighted through a comparative angle: participants asked what the standard for equality was. It was suggested that this could be measured by 50-50 quotas (which resulted in some debate) or by comparing gender equality in the UN to another international organisation.

Several groups asked how the UN measures gender inequality and how they monitor the practices. It appeared that the UN use internal methods to examine this and this resulted in a discussion around the ethical implications this creates. Furthermore, it was suggested that the reports created on gender inequality within the UN thus far seemed very broad and would benefit from, for example, considering gender inequality at various levels of employment within the UN and in different countries. It was concluded that an intersectional approach needed to be deployed.

The general question of access to statistics was raised as it was claimed that reports are either non-existent or not accessible. It was also suggested that qualitative data would be beneficial alongside quantitative data.

\section{b) Barriers to gender inequality}

The members were asked to think about what some of the key barriers to gender inequality may be. The group's feedback that the concept of gender itself can act as a barrier for example, issues with self-identification and the gender/sex binary being reinforced in workplaces through the architecture itself, for example not having gender neutral bathroom facilities. 
Childcare may also be a barrier to gender equality within the UN. The group were interested in learning more about what policies the UN has for childcare, such as their breastfeeding policy. It was also suggested that eldercare may also be a barrier to gender equality within the UN as it is often female members of the family who are tasked with looking after older relatives. The issue of reintegration after time away from work due to familial commitments may also act as a barrier.

The implementation and practical application of the Gender Champion Initiative is questionable: it appears that they are only allowed to dedicate a percentage of their time to gender work while working on other things. It was suggested that this role should be full time. At present, however, it appears as though this role is a token gesture. Further issues lie with the possibility that a Gender Champion, supposedly initiated to represent women's issues, could potential be a male. Practical questions were raised on this point, i.e. can a man represent women's issues and, if so, how?

\section{c) Sex vs Gender}

The issue of the name of the network, and as a result, the paradigms of the network were called into question. It was asked why the network is not referring to sex equality or equality between men and women. It was suggested that gender is a social construct, and as the purpose of the network is to look at policies within the UN, we as a network should be considering socially constructed barriers. It was also claimed that if the network used the term gender, it would allow for a more textured approach to issues as opposed to the sex binary. It was concluded that language is important and that this issue should be seriously considered.

Discussions also centred on who is included when we use the term 'women.' The question of whether this should include transwomen was discussed. It was concluded that barriers for CIS women may be different than that of transwomen and should therefore be excluded from the parameters of the network. Moreover, it was emphasised that there are different approaches across different UN member states, and that using 'gender' would provide a barrier to any proposals being successful. It was emphasised that this must be explicitly 
stated in the Network's manifesto or introductory statement, and that there ought to be a section explaining the reasons behind this approach. 


\section{Conclusion}

The first workshop of the UN Gender Network provided an introduction to the Network and an opportunity for the participants to shape and hone the Network aims and future activities. The workshop provided a platform for facilitating discussion on the issues that the Network should to address before developing its strategy It was also useful for members to meet one another and to develop contacts within the Network. It was proposed that members email the organisers with suggested contacts that could be involved with the network, which has resulted in many new names being added to the mailing list. 
Appendix 1

\begin{tabular}{|c|c|}
\hline Name & Organisation /area \\
\hline Dr Aoife O’Donoghue & Durham University \\
\hline Professor Rosa Freedman & Reading University \\
\hline FCO & $\begin{array}{l}\text { Anne Jenkins } \\
\text { John Wattam }\end{array}$ \\
\hline Alice Panepinto & Warwick University \\
\hline Sophie Payne & Reading University, PhD \\
\hline Prof Joohee Lee & Ewha Womans University, Sociology, Gender, Employment, \\
\hline Joanne Payton & Fuuuse \\
\hline Maria Tomlinson & Reading Univeristy, PhD \\
\hline Jane Connors & Amnesty \\
\hline Dr. Catherine Turner/Ross & Durham, Women \& Mediation UN \\
\hline Noelle Takahashi & $\begin{array}{l}\text { Vice Chairman of Policy Commission, Tokyo Junior Chamber International } \\
\text { Gender }\end{array}$ \\
\hline Dr. Fabia Vecoso & Post doc Melbourne, Global Governance, IR \\
\hline Jane Hodges & Independent Consultant on Women's Rights \\
\hline Rosalyn Park & Director, Women's Human Rights Program, The Advocates for Human Rights \\
\hline Raphael Crowe. & Senior Gender Specialist, Gender and Equality Branch, ILO \\
\hline Kim Barker & Stirling University \\
\hline Jacqui Hunt-nudged & UK Director of Equality Now \\
\hline Elise Dietrichson & SOAS \\
\hline Fatima Sator & SOAS \\
\hline Shanthi Dairiam & Founder of IWRAW-Asia Pacific \\
\hline Georgia White & AFW \\
\hline Georgina Holmes & Reading University \\
\hline Sophie Doherty & Durham University, PhD \\
\hline
\end{tabular}

